\title{
PROFIL EKSTRA PARU TUBERKULOSIS SECARA HISTOPATOLOGIK PADA FORMALIN FIXED PARAFFIN EMBEDDED (FFPE) DI PROVINSI JAMBI
}

\author{
Fairuz $^{1}$, Hasna Dewi ${ }^{1}$ Humaryanto $^{2}$ \\ ${ }^{1}$ Bagian Patologi Anatomi ,Fakultas Kedokteran dan Ilmu Kesehatan Universitas Jambi Universitas Jambi \\ ${ }^{2}$ Bagian Bedah ,Fakultas Kedokteran dan IImu Kesehatan Universitas Jambi Universitas Jambi \\ Email: fairuzquzwain@gmail.com
}

\begin{abstract}
Background Extrapulmonary Tuberculosis (EPTB) is a condition in tissue outside the lung that is characterized pathologically with extensive involvement of lymphocyte inflammation cells, the presence of epitheloid granuloma cells in the langhans and the duration of the cancer. Tuberculosis (TB) remains a major global public health problem, with 1.5 million deaths every year worldwide.. Histopathologic variations in the appearance of the diagnosis of EPTB often overlap commonly with granulomatous inflammation. This study aims to describe the EPTB profile histopathologically on FFPE samples in Jambi province.
\end{abstract}

Methods This research is a descriptive study with cross sectional technique, evaluating the histopathological picture of EPTB on formalin Fixed Paraffin Emdedded (FFPE) preparations. The study was conducted in February - August 2019 in the Anatomy Pathology Laboratory of the Faculty of Medicine and Health Sciences and FFPE samples originating from Hospitals in Jambi Province. Histopathological data are divided into 3 categories: non-specific chronic mastitis, granulomatous chronic mastitis and specific chronic mastitis. Histopathological variables were assessed by histopathological score.

Result Obtained 72 FFPE EPTB tissues from hospitals in Jambi Province, mostly originating from lymph nodes as much as $58.3 \%$ followed by breasts as much as $16.5 \%$. The most common histopathopathic picture is in accordance with tuberculosis (EPTB) as much as $54.2 \%$ and cases of granulomatous inflammation which is still high as much as $44.4 \%$. Histopathological picture of EPTB fulfills all tuberulosis criteria (100\%), in contrast to granulomatous inflammation only fulfills 2 criteria, namely lymphocytes and epithelioid.

Conclusions Histopathological picture of extrapulmonary tuberculosis in histopathology for the most part still gives a classic picture.

Key Words : Histopathology, Extrapulmonal Tuberculosis, Formalin Fixed Paraffin Embedded (FFPE) 


\begin{abstract}
ABSTRAK
Latar Belakang Ektrapulmonal Tuberkulosis (EPTB) adalah suatu kondisi pada jaringan diluar paru yang ditandai secara patologi dengan keterlibatan secara ekstensif sebukan sel radang limfosit, adanya granuloma epitheloid sel datia langhans dan masa perkijuan. Tuberkulosis (TB) tetap menjadi masalah kesehatan masyarakat global utama, dengan 1,5 juta kematian setiap tahun di seluruh dunia. Diagnosis untuk kasus EPTB pada jaringan saat ini secara umum masih menggunakan pemriksaan patologi anatomi. Adanya berbagai variasi gambaran secara histopatologis mmebuat diagnosis EPTB seringkali tumpang tindih terumata dengan radang granulomatosa. Penelitian ini bertujuan untuk menggambarkan profil EPTB secara histopatologik pada sampel FFPE di provinsi Jambi.
\end{abstract}

Metode Penelitian ini adalah penelitian deskriptif dengan teknik cross sectional, menilai gambaran histopatologis EPTB pada sediaan Formalin Fixed Paraffin Emdedded (FFPE). Penelitian dilaksanakan pada Bulan Februari - Agustus 2019 di Laboratorium Patologi Anatomi Fakultas Kedokteran dan IImu Kesehatan dan sampel FFPE yang berasal dari Rumah Sakit di Provinsi Jambi. Data histopatolgis dibagi menjadi 3 kategori yaitu: mastitis kronis non spesifik, mastitisn kronis granulomatosa dan mastitis kronis spesifik. Variabel histopatologi yang dinilai dengan skor histopatologis.

Hasil Didapatkan 72 jaringan FFPE EPTB dari Rumah Sakit di Provinsi Jambi, paling banyak berasal dari kelenjar getah bening sebanyak 58,3\% diikuti dengan payudara sebanyak 16,5\%. Gambaran histopatolgois paling banyak adalah sesuai dengan tuberculosis (EPTB) sebanyak $54,2 \%$ dan kasus radang granulomatosa yang masih tinggi yaitu sebanyak 44,4\%. Gambaran histopatologis EPTB memenuhi semua kriteria tuberulosis (100\%), berbeda dengan radang granulomatosa hanya memenuhi 2 kriteria yaitu sebukan limfiosit dan gambaran epitelioid.

Kesimpulan gambaran histopatologis ekstra paru tuberkulosis secara histopatologis paling banyak ditemukan di kelenjar getah bening dan sebagian besar masih memberikan gambaran yang klasik.

\title{
Kata Kunci : Histopatologi, Tuberkulosis Ekstra Paru, Formalin Fixed Parafin Embedded (FFPE)
}

\section{PENDAHULUAN}

Tuberkulosis (TB) adalah penyakit menular yang disebabkan oleh bacillus Mycobacterium tuberculosis. Penyakit Ini terutama mempengaruhi paru-paru (TB paru [PTB]), tetapi bentuk penyakit yang lebih lanjut dapat mempengaruhi organ dan jaringan lain (ekstraPTB [EPTB]). TB adalah salah satu penyakit menular yang paling penting secara global, dengan perkiraan Organisasi Kesehatan Dunia (WHO) menyarankan bahwa pada tahun 2014 (menggabungkan data untuk orang dewasa dan anak-anak), ada sekitar 9,6 juta kasus TB dan 1,5 juta kematian, di mana 400.000 di antaranya adalah pada pasien koinfeksi dengan human immunodeficiency virus (HIV). ${ }^{1,2}$

Penyakit EPTB terjadi di tempat-tempat selain paru-paru, termasuk laring, kelenjar getah bening, pleura, otak, ginjal, atau tulang dan persendian. ${ }^{3}$ Setelah penyebaran basil limfatik atau hematogen selama infeksi paru primer, basil basil 
tuberkel menetap di tempat tubuh yang berbeda, berlipat ganda, dan memperoleh respons imun inang, yang menghasilkan pembentukan granuloma dengan nekrosis kaseous dan sel raksasa tipe Langhans, serangkaian tanda yang dikenal sebagai gambaran histopatologis klasik TB. ${ }^{4}$ Definisi "standar emas" infeksi TB ini tidak membedakan M TBC dari mikobakteri lain; nekrosis caseous sentral tidak selalu terlihat pada biopsi kecil, dan ada kemungkinan kondisi granulomatosa lainnya., ${ }^{4,5}$ Mendiagnosis EPTB secara akurat secara mikrobiologis juga sulit karena memerlukan pengambilan sampel biopsi invasif dari jaringan paucibacillary atau cairan (misalnya, cairan serebrospinal [CSF]), yang mungkin memiliki volume terbatas dan memiliki distribusi basil yang tidak seragam. Modalitas pemeriksaan Ziehl-Neelsen (ZN) mengkonfirmasi keberadaan mikobakteri asam-cepat tetapi tidak spesifik untuk M. tuberculosis. Membiakkan M. tuberculosis dari jaringan mungkin tersedia di beberapa laboratorium, tetapi ini membutuhkan spesimen steril baru, adalah sumber daya intensif yang membutuhkan fasilitas laboratorium Tingkat Keamanan Hayati (BSL-3), dan tidak dipraktikkan secara rutin di luar rumah sakit besar yang berfokus pada penelitian. Oleh karena itu, ada banyak minat dalam beberapa tahun terakhir pada penerapan diagnostik molekuler spesifik $\mathrm{M}$. tuberculosis, yang awalnya dikembangkan untuk menguji DNA $M$. tuberculosis dalam spesimen pernapasan, untuk diagnosis EPTB yang cepat dan akurat (dan EPTB yang resistan terhadap obat) menggunakan berbagai jenis spesimen biopsi. ${ }^{6,7,8}$

Provinsi Jambi adalah salah astu daerah endemis kejadian infeksi spesifik, data yaang akurat didapatkan untuk kejadian TB, tetapi data yang signifikan untuk kejadian infeksi EPTBpada saat ini masih belum jelas. Sehingga diperlukan adanya data profil histopatologis EPTB. Penelitia ini menggunakan profil histopatologis sebagai salah satu standar penegakkan diagnosis pada EPTB, bertujuan untuk mengetahui profil histopatologi EPTB pada sediaan Formalin Fixed Paraffin Embedded (FFPE) di Provinsi Jambi

\section{BAHAN DAN METODE PENELITIAN}

Penelitian ini adalah penelitian deskriptif dengan teknik cross sectional, menilai gambaran histopatologis EPTB pada sediaan Formalin Fixed Paraffin Emdedded (FFPE). Penelitian dilaksanakan pada Bulan Februari - Agustus 2019 di Laboratorium Patologi Anatomi Fakultas Kedokteran dan IImu Kesehatan dan sampel FFPE yang berasal dari Rumah Sakit di Provinsi Jambi. Sampel yang digunakan dalam penelitian ini adalah semua pasien yang dilakukan pemeriksaan histopatologis dan memenuhi kriteria secara klinis sebagai EPT, pada periode Januari 2017- April 2019. Sebelum dilakukan penilaian terhadap variabel histopatologis, sampel FFPE diperiksa ulang untuk kelengkapa data klinis dan kondisi blok FFPE yang akan dinilai. Data histopatolgis dibagi menjadi 3 kategori yaitu : mastitis kronis non spesifik, mastitisn kronis granulomatosa dan mastitis kronis spesifik. Variabel histopatologi yang dinilai adalah: 1. Sebukan sel limfosit, 2. Adanya sel epitelioid, 3. Terdapat sel datia langhans, 4. Ditemukan nekrosis perkijuan 5. Terdapat fibrosis 6. Terdapat pembentukan hyaline 7. Adanya sel berinti banyak tetapi tidak khas datia langhans 8 . Adanya sel PMN. Kriteria 1-4 adalah kriteria 
primer, kriteria 6-9 adalah kriteria sekunder (penyerta). Pada kategori: A. Radang non TB memenuhi syarat $1,5,6,8$. B. Radang granulomatos : $1,2,5,6,7,8$. C. EPTB: 1,2,3,4,5,6,7,8. Hasil disajikan dalam bentuk tabel dan dihitung dalam bentuk persentase. ${ }^{9}$

\section{HASIL}

Didapatkan 72 jaringan FFPE EPTB dari Rumah Sakit di Provinsi Jambi yang berasal dari kelenjar getah bening $(n=42)$, testis / skrotum ( $n$ $=3$ ), Intra abdomen ( $n=2)$, ovarium $(n=2)$, jaringan payudara $(n=12)$, jaringan sinovial $(n=$ $2)$, kulit $(n=2)$, prostat $(n=2)$, dan ginjal $(n=1)$, saluran intestinal $(n=4)$ dengan data profil klinis sebagaimana ditampilkan dalam tabel karakteristik klinis pada tabel 1.

Tabel 1 Karakterstik klinis EPTB

\begin{tabular}{lc}
\hline \multicolumn{1}{c}{ Variabel } & $\mathbf{N}=\mathbf{6 8}$ \\
\hline Usia (tahun) & $30,09 \pm 12,06$ \\
Rata-rata \pm SD & 34,50 \\
Median & $13,00-73,00$ \\
Rentang (min-maks) & \\
Jenis Kelamin & 40 \\
Laki-laki & 32 \\
Perempuan & \\
Ukuran tumor (cm) & $3,50 \pm 9,50$ \\
Rata-rata $\pm S D$ & 6,50 \\
Median & $2,25-12,00$ \\
Rentang (min-maks) & \\
Lokasi & $42(58,3 \%)$ \\
Kelenjar getah bening & $3(4,2 \%)$ \\
Testis/skrotum & $2(2.8 \%)$ \\
Intraabdomen & $2(2.8 \%)$ \\
Ovarium & $12(16,5 \%)$ \\
Payudara & $2(2.8 \%)$ \\
Jaringan sinovial & $2(2,8 \%)$ \\
Kulit & \\
\hline
\end{tabular}

\begin{tabular}{ll}
\hline Prostat & $2(2,8 \%)$ \\
Ginjal & $1(1,4 \%)$ \\
Saluran instestinal & $4(5,6 \%)$ \\
\hline
\end{tabular}

Sampel blok FFPE dilakukan penilaian ulang dengan pewarnaan hematoksilin eosin dan pemeriksaan Ziehl Nielsen. Secara histopatologis dibagi menjadi : Radang non TB, Radang granulomatosa dan EPTB. Hasil profil histopatologis dapat dilihat dalam tabel 2.. Dari tabel 2 tampak EPTB paling banyak ditemukan dari semua jenis histopatologis sebanyak 39 orang (54,2\%), diikuti dengan Radang garnulomatosa sebanyak 32 orang ( $44,4 \%)$ dan radang Non TB sebanyak 1 orang $(1,4 \%)$. Variabel paling dominan pada radang non TB adalah serbukan sel radang limfosit, tidak ada gambaran khas yang lain yang lebih dominan.

Dari tabel 2 tampak EPTB paling banyak ditemukan dari semua jenis histopatologis sebanyak 39 orang ( $54,2 \%)$, diikuti dengan Radang garnulomatosa sebanyak 32 orang ( 44,4 $\%)$ dan radang Non TB sebanyak 1 orang $(1,4 \%)$. Variabel paling dominan pada radang non TB adalah serbukan sel radang limfosit, tidak ada gambaran khas yang lain yang lebih dominan.

Gambaran histopatologis radang granulomatosa paling banyak adalah serbukan sel radang lim. fosit serta adanya proliferasi sel epitelioid tanpa disertai dengan perkijuan, sedangkan mastitis spesifik juga disertai dengan perkijuan dan sel epitelioid Gambaran mikroskopis dapat dilihat pada gambar 1 tampak bahwa pada radang granulmatosa tidak ada sampel yang mengandung nekrosis perkijuan, dan sangat jelas pada EPTB. 
Tabel 2 Karakteristik Histopatologi

\begin{tabular}{|c|c|c|c|c|c|c|c|c|c|}
\hline \multirow{2}{*}{ Jenis Radang } & \multirow{2}{*}{$\mathrm{N}$} & \multicolumn{8}{|c|}{ Variabel Histopatologi } \\
\hline & & 1 & 2 & 3 & 4 & 5 & 6 & 7 & 8 \\
\hline & 1 & & & & & & & & \\
\hline \multirow[t]{2}{*}{ Radang non TB } & $(1.4 \%)$ & 1 & 0 & 0 & 0 & 1 & 1 & 1 & 1 \\
\hline & & $100 \%$ & $0 \%$ & $0 \%$ & $0 \%$ & $100 \%$ & $100 \%$ & $100 \%$ & $100 \%$ \\
\hline \multirow[t]{2}{*}{$\begin{array}{l}\text { Radang } \\
\text { granulomatosa }\end{array}$} & $\begin{array}{c}32 \\
(44,4 \%)\end{array}$ & 32 & 32 & 0 & 0 & 4 & 6 & 5 & 0 \\
\hline & & $100 \%$ & $100 \%$ & $0 \%$ & $0 \%$ & $12,5 \%$ & $18,75 \%$ & $15,6 \%$ & $0 \%$ \\
\hline \multirow{3}{*}{ EPTB } & 39 & 39 & 39 & 39 & 35 & 8 & 6 & 0 & 0 \\
\hline & $(54,2 \%)$ & & & & & & & & \\
\hline & & $100 \%$ & $100 \%$ & $100 \%$ & $89,7 \%$ & $20,5 \%$ & $15,4 \%$ & $0 \%$ & $0 \%$ \\
\hline Total & 72 & 72 & 71 & 39 & 35 & 13 & 13 & 6 & 1 \\
\hline
\end{tabular}

a.

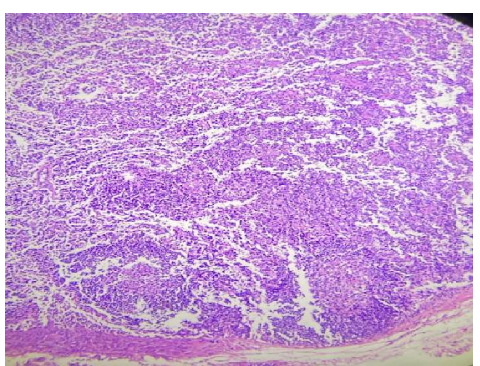

b.
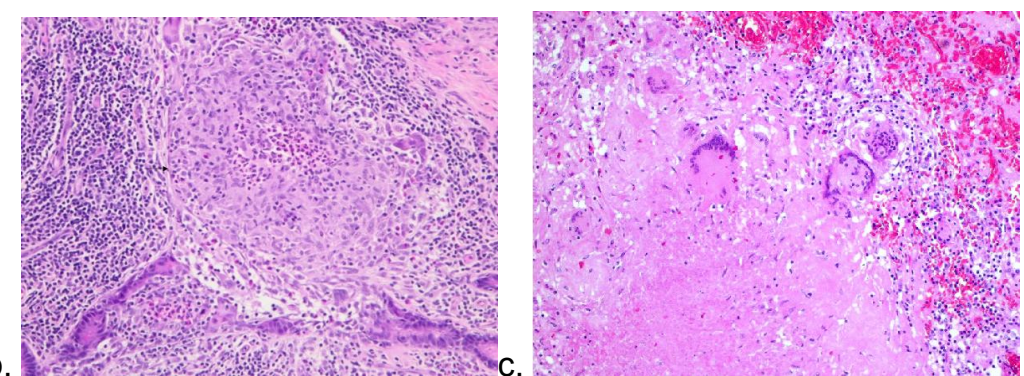

Gambar 1. a. Radang non TB b.Radang Granulomatosa c. EPTB (Olympus,400x

\section{PEMBAHASAN}

Ektrapulmonal Tuberkulosis (EPTB) adalah suatu kondisi pada jaringan diluar paru yang ditandai secara patologi dengan keterlibatan secara ekstensif sebukan sel radang limfosit, adanya granuloma epitheloid sel datia langhans dan masa perkijuan. ${ }^{5,10}$ Penyakit ini tetap menjadi masalah kesehatan masyarakat global utama, dengan 1,5 juta kematian setiap tahun di seluruh dunia. Menurut laporan WHO pada tahun 2013, prevalensi TB di Indonesia menempati urutan ketiga setelah India dan Cina, yang hampir 700 ribu kasus, angka kematian masih 27/100 ribu orang. Jumlah penderita Tuberkulosis (TB) di kota Jambi terus meningkat setiap tahun. Pada 2015 ditemukan 552 kasus TB, 2016 meningkat menjadi 902 kasus dan pada 2017 meningkat menjadi 1070 kasus TB. Kasus EPTB di dunia berdasarkan Global Tuberculosis Report 2013 tercatat sebanyak 0,8 juta kasus pada tahun 2012. Kasus EPTB di Indonesia berjumlah 15.697 dari semua kasus TB baru berjumlah 331.424. Satu dari lima kasus TB hadir sebagai EPTB, menghadirkan tantangan diagnostik dan 
manajemen utama. ${ }^{11,12,13}$ Biasanya disebabkan oleh reaktivasi infeksi laten dan dapat menyebabkan penyakit di hampir semua lokasi. Ekstrapulmonal TB mengacu pada TB yang melibatkan organ selain paru-paru, paling banyak kelenjar getah bening (23\%), pleura $(8,2 \%)$, saluran pencernaan $(5,9 \%)$, tulang $(6,7 \%)$, sistem saraf pusat $(4,4 \%)$ dan genitourinari sistem $(2,1 \%) .{ }^{14}$ Pada penelitian ini didapatkan paling banyak pada kelenjar getah bening sebanyak $58,3 \%$ diikuti dengan payudara sebanyak $16,5 \%$. Pada gambaran histopatologik, didapatkan sbeagian besar kasus memberikan gambaran ynag cukup klasik untuk tuberculosis. Hal yang sangat menarik adalah, ditemukan sebanyak $44,4 \%$ kasus dengan gambaran histopaotlogik sesuai dengan radang granulomatosa. Radang granulomatous merupakan salah satu tantangan dalam penegakan diagnosis tuberkulosis pada jaringan FFPE. Hal ini disebabkan, banyak keterkaitan gambaran granulomatosa dengan proses tuberkulosis, infeksi toksoplasmosis, mononukelosis, sarkodosis bahkan limfoma Hodgkin. $^{15,16,17}$ Hal ini menyebabkan perlu dilakukan pemeriksaan lanjutan secara lebih spesifik dalam penegakan diagnosis tuberculosis. Gambaran granulomatosis ini juga ditemukan banyak pada payudara, pada penelitian ini sampel FFPE radang granulomatosis paling banyak ditemukan pada payudara yaitu sebanyak $37,5 \%$ kasus diikuti dengan kelenjar getah bening sebanyak $18,75 \%$ kasus.

\section{KESIMPULAN}

Pada penelitian ini dapat disimpulkan bahwa gambaran histopatologis ekstra paru tuberkulosis secara histopatologis paling banyak ditemukan di kelenjar getah bening dan sebagian besar masih memberikan gambaran yang klasik.

\section{DAFTAR PUSTAKA}

1. Report GT. Global Tuberculosis Report WHO 2018. Vol 69.; 2018.

2. Global Tuberculosis Report 2013 (WHO). Tuberculosis country profiles. Nepal. 2013.

3. Peirse M, Houston A. Extrapulmonary tuberculosis. Med (United Kingdom). 2017;45(12):747-752. doi:10.1016/j.mpmed.2017.09.008

4. Park KH, Munkhdelger J, Lee D, et al. Performance of real time PCR and dual ID REBA for detection of tuberculosis in granulomatous lymphadenitis using formalin fixed paraffin embedded tissue (FFPE). Histopathology.2012;61:164.

http://www.embase.com/search/results?subaction=viewrecord\&from=export\&id=L70934517\%5Cnhttp://dx.doi .org/10.1111/j.1365-2559.2012.04359-17.x.

5. Wainwright HC. Histopathology. In: Clinical Tuberculosis, Fifth Edition. ; 2014:79-92. doi:10.1201/b16604

6. Rindi L, Alì G, Fabiani B, Fontanini G, Garzelli C. Detection of Mycobacterium tuberculosis from paraffinembedded tissues by GeneXpert MTB/RIF. Tuberculosis. 2017;106:53-55. doi:10.1016/j.tube.2017.06.005

7. YAĞMUR G, ALBAYRAK N, DAŞ T, YILDIRIM M, ÖZGÜN A, BÜYÜK Y. Comparison of Two Different RealTime PCR Systems in Postmortem Diagnosis of Tuberculosis in Paraffin-Embedded Tissues. Mikrobiyol Bul. 2014;48(4):577-584. doi:10.5578/mb.8299

8. Mehta PK, Raj A, Singh N, Khuller GK. Diagnosis of extrapulmonary tuberculosis by PCR. FEMS Immunol 
Med Microbiol. 2012;66(1):20-36. doi:10.1111/j.1574-695X.2012.00987.x

9. Sopiyudin Dahlan M. Besar Sampel dan Cara Pengambilan Sampel dalam Penelitian Kedokteran dan Kesehatan. Salemba Med. 2013:73.

10. Peirse M, Houston A. Extrapulmonary tuberculosis. Med (United Kingdom). 2017;45(12):747-752. doi:10.1016/j.mpmed.2017.09.008

11. Kementerian Kesehatan Republik Indonesia. Tuberkulosis ( TB ). Tuberkulosis. $2018 ; 1$. www.kemenkes.go.id.

12. Fuady A, Pakasi TA, Mansyur M. The social determinants of knowledge and perception on pulmonary tuberculosis among females in Jakarta, Indonesia. Med $J$ Indones. 2014;23(2):93-105. doi:10.13181/mji.v23i2.651

13. Report GT. Global Tuberculosis Report 2016, World Health Organization. Http://AppsWholnt//ris/Bitstream/10665/91355/1/9789241564656_EngPdf. 2016:2014-2016.

14. Diego VS, Gabriela RR, Vanessa ST. Extrapulmonary tuberculosis. Rev Bionatura. 2020;5(1):1066-1071. doi:10.21931/RB/2020.05.01.10

15. Shah SA, Ali M, Hamdan U. Extrapulmonary tuberculosis and cervical lymphadenopathy. Pakistan J Med Heal Sci. 2015;9(4):1282-1285.

16. Al-Radi LS, Moiseeva TN, Chernova NG, et al. Tuberculosis in patients with lymphoproliferative diseases. Ter Arkh. 2014;86(11):42-49.

17. Soussan M, Augier A, Brillet $P-Y$, Weinmann $P$, Valeyre D. Functional Imaging in Extrapulmonary Sarcoidosis. Clin Nucl Med. 2014;39(2):e146-e159. doi:10.1097/rlu.0b013e318279f264 